\title{
Activity pattern of medium and large sized mammals and density estimates of Cuniculus paca (Rodentia: Cuniculidae) in the Brazilian Pampa
}

\author{
C. Leuchtenberger ${ }^{*}$, E. S. de Oliveira ${ }^{b}$, L. P. Cariolatto ${ }^{c}$ and C. B. Kasper ${ }^{b}$ \\ ${ }^{a}$ Instituto Federal Farroupilha - IFFAR, Coordenação de Ciências Biológicas, Rua Erechim, nº 860, Campus Panambi, \\ CEP 98280-000, Panambi, RS, Brazil

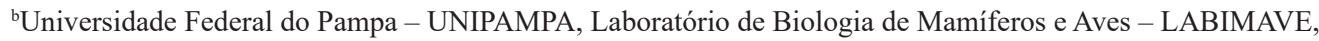 \\ Av. Antônio Trilha, nº 1847, CEP 97300-000, São Gabriel, RS, Brazil \\ 'Instituto Federal Farroupilha - IFFAR, RS-377, Km 27, Campus Alegrete, Passo Novo, CEP 97555-000, \\ Alegrete, RS, Brazil \\ *e-mail: caroleucht@gmail.com
}

Received: January 13, 2017 - Accepted: June 26, 2017 - Distributed: November 30, 2018

(With 2 figures)

\begin{abstract}
Between July 2014 and April 2015, we conducted weekly inventories of the circadian activity patterns of mammals in Passo Novo locality, municipality of Alegrete, southern Brazil. The vegetation is comprised by a grassy-woody steppe (grassland). We used two camera traps alternately located on one of four $1 \mathrm{~km}$ transects, each separated by $1 \mathrm{~km}$. We classified the activity pattern of species by the percentage of photographic records taken in each daily period. We identify Cuniculus paca individuals by differences in the patterns of flank spots. We then estimate the density 1) considering the area of riparian forest present in the sampling area, and 2) through capture/recapture analysis. Cuniculus paca, Conepatus chinga and Hydrochoerus hydrochaeris were nocturnal, Cerdocyon thous had a crepuscular/nocturnal pattern, while Mazama gouazoubira was cathemeral. The patterns of circadian activity observed for medium and large mammals in this Pampa region (southern grasslands) may reflect not only evolutionary, biological and ecological affects, but also human impacts not assessed in this study. We identified ten individuals of $C$. paca through skin spot patterns during the study period, which were recorded in different transects and months. The minimum population density of C. paca was 3.5 individuals per $\mathrm{km}^{2}$ (resident animals only) and the total density estimates varied from 7.1 to 11.8 individuals per $\mathrm{km}^{2}$, when considering all individuals recorded or the result of the capture/recapture analysis, respectively.
\end{abstract}

Keywords: abundance, circadian activity, camera trap, terrestrial mammals, south grasslands.

\section{Padrão de atividade de mamíferos de médio e grande porte e estimativa da densidade de Cuniculus paca (Rodentia: Cuniculidae) no Pampa brasileiro}

\begin{abstract}
Resumo
De julho de 2014 a abril de 2015, realizamos levantamentos semanais para estudar padrões de atividade circadiana da mastofauna na localidade de Passo Novo, Alegrete, sul do Brasil. A vegetação é compreendida por savana estépica (campo). Utilizamos duas armadilhas fotográficas distribuídas alternadamente ao longo de quatro transectos, com extensão de $1 \mathrm{~km}$ e distantes cerca de $1 \mathrm{~km}$ entre si. Nós classificamos o padrão de atividade das espécies através da percentagem de fotos registradas em cada período diário. Nós identificamos indivíduos de Cuniculus paca através dos diferentes padrões de manchas nos flancos dos animais. Nós então estimamos a densidade 1) considerando a área de floresta ripária presente na área amostrada, e 2) através da análise de captura/recaptura. As espécies Cuniculus paca, Conepatus chinga e Hydrochoerus hydrochaeris foram classificadas como noturnas, Cerdocyon thous apresentou um padrão crepuscular/noturno, enquanto Mazama gouazoubira foi classificada como catemeral. O padrão de atividade circadiana observado para os mamíferos de médio e grande porte nessa região do Pampa (campos sulinos) pode refletir não só aspectos evolutivos, biológicos e ecológicos, mas também impactos humanos não avaliados nesse estudo. Através do padrão de manchas da pelagem de C. paca nós identificamos dez indivíduos durante o período de estudo, que foram registrados em diferentes transectos e meses. A densidade populacional mínima de $C$. paca foi de $3,5 \mathrm{ind} / \mathrm{km}^{2}$ (apenas indivíduos residentes) e a densidade total variou de 7,1 a $11,8 \mathrm{ind} / \mathrm{km}^{2}$, quando consideramos todos os indivíduos registrados ou com base em análises de captura e recaptura, respectivamente.
\end{abstract}

Palavras-chave: abundância, atividade circadiana, armadilha fotográfica, mamíferos terrestres, campos sulinos. 


\section{Introduction}

The activity pattern of a species is an important aspect of its ecology, reflecting physiological characteristics and ecological interactions (Tobler et al., 2009; Norris et al., 2010; Blake et al., 2012). The activity rhythm of most species is regulated by endogenous biogeochemical processes that are mostly stimulated by cyclical environmental variations, such as the daily photoperiod (Dibner et al., 2010). In general, species regulate their activity according to the daily light-dark cycle and may specialize in a particular period. This allows their classification as diurnal or nocturnal, crepuscular or even cathemeral (Mistlberger and Antle, 2011).

The circadian rhythms of mammals may also be affected by factors other than light, including food availability and social stimulus, competition, predation and maternal behavior (Mistlberger and Skene, 2004). Human disturbances, such as habitat fragmentation, tourism and hunting, can also be important factors in determining mammalian activity pattern (Kitchen et al., 2000; Martin and Reále, 2008; Norris et al., 2010). Consequently, variations in activity pattern among populations may represent strategies adopted by individuals to deal with locally limiting factors, such as ecological interactions, environmental cues and different intensities of threat.

Brazil has one of the highest mammal diversities in the world, with more than 700 species known (Paglia et al., 2012). According to Costa et al. (2005), 13\% of the 66 threatened species in Brazil occur in the Pampa Biome. This region is dominated by grasslands and has been used for many generations for raising livestock. Currently, the main impacts include the expansion of soybean cultivation and silviculture based on Pinus spp. and Eucalyptus spp. (Hasenack and Cordeiro, 2006). Despite this wide array of threats, mammal surveys in the Brazilian Pampas are limited (Kasper et al., 2012a, b; Pinto and Duarte, 2013; Espinosa et al., 2016), especially regarding mammalian ecology and activity patterns.

The recent discovery of Cuniculus paca (Linnaeus, 1766) in the Pampas (Leuchtenberger et al., 2016) underscores how poorly known is the mammalian assemblage of this biome. Although the species is widespread in Central and South America, it is threatened by hunting and habitat loss in some regions (Gudynas, 1989; Beck-King et al., 1999; Wright et al., 2000; Emmons, 2016). Cuniculus paca is one of the World's largest rodents, measuring about $70 \mathrm{~cm}$ long and weighting up to $10 \mathrm{~kg}$ (Silva, 2014). The species has a compact and sturdy body, a naked and short tail. Dorsal pelage ranges from red brown to dark chocolate with white spots on the flanks (Pérez, 1992). Variations in the patterns of which can be used to identify individuals (Foster and Harmsen, 2011). Studies of C. paca activity patterns are limited (Michalski and Norris, 2011), and no standardized methodology exists to provide accurate census information; consequently population density estimates range from 3.5 to $93 \mathrm{ind} / \mathrm{km}^{2}$ (Emmons, 1987; Eisenberg and Redford, 1999; Aquino et al., 2009; Santos-Moreno and Perez-Irineo, 2013; Patton, 2015).

Given the lack of information about activity patterns of mammals in the Brazilian Pampa, especially C. paca, and the importance of this knowledge for conservation management, the objectives of this study were to analyze the circadian activity pattern of medium- and large-sized mammals in a typical Pampa region in the southern Brazil, and to infer information about C. paca population density.

\section{Material and Methods}

\subsection{Study areas}

The study was conducted at the Passo Novo region in the municipality of Alegrete, Rio Grande do Sul State, southern Brazil (Figure 1). The study area (2941'49”'S, 55³2'11'O) is located in the Pampa Biome, according to IBGE (2004). The Pampa domain extends about $176,500 \mathrm{~km}^{2}$ within the Brazilian territory, and comprises $63 \%$ of the land surface of Rio Grande do Sul State (IBGE, 2004). The climate is temperate wet with warm summers (Cfa, Köppen, 1948), and the landscape is comprised of extensive grasslands plains with some undulations and hills of silicified sandstone.

Vegetation of the study site is classified as grassy-woody steppe (native grassland), modified by constant cattle pasture pressure. Forested areas are limited to riparian vegetation composed of Seasonally Deciduous Alluvial vegetation (IBGE, 2012). The survey was conducted along the riparian forest of the Lajeado Grande Stream.

\subsection{Data collection}

A survey of medium and large mammals was conducted from July 2014 to April 2015 using two camera traps (Bushnell® Trophy Cam tm, model: 119436c). We established four consecutive transects of $1 \mathrm{~km}$ length and $1 \mathrm{~km}$ distant from each other. Each transect was sampled for a week per month, during 10 months, with cameras positioned 200 to 400 meters from each other. So, each transect was sampled 10 times with two cameras. This arrangement resulted in a sample effort of 534 trap nights. Camera traps were configured to take three sequential records when activated, with a minimum interval between events of 30 seconds. The camera traps remained active along 24 hours a day, and we did not use bait during sampling.

\subsection{Data analysis}

Activity patterns of surveyed species were analyzed using images of the same species taken at intervals of $\geq 1 \mathrm{~h}$ from each transect. To establish activity patterns, we analyzed the temporal patterns of records using Oriana 4.0 software (Kovach, 2011). Analysis was restricted to species with more than 10 independent photographic records.

We classified each photographic record as diurnal, nocturnal or crepuscular according with the time of local sunrise and sunset, using Moonrise 3.5 software (Sidell, 2002). We adapted the system proposed by Gómez et al. (2005) and classified the activity pattern of each species based on the percentage of independent records in each period: 


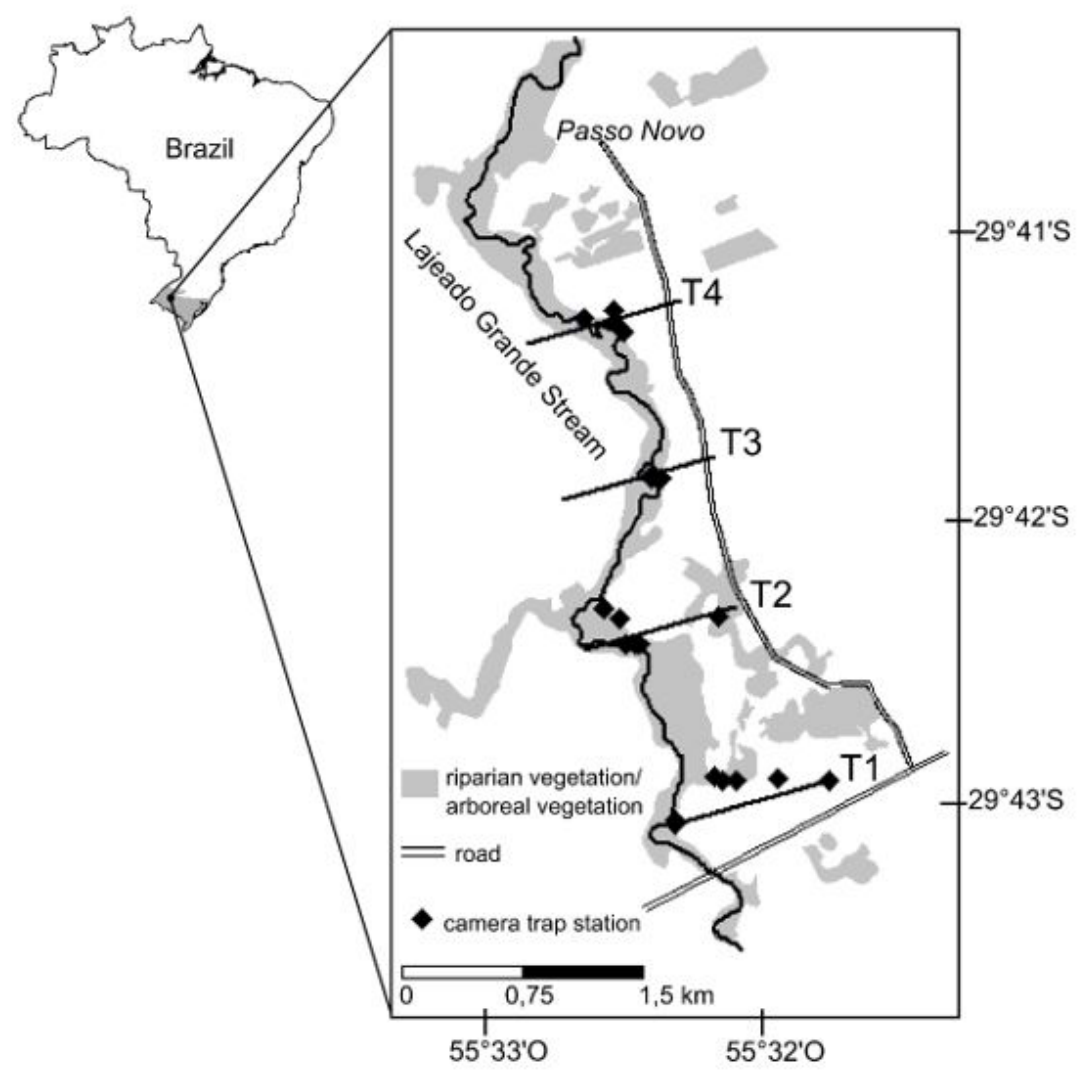

Figure 1. Map of the study area, showing the location of camera trap stations along four transects (T1 - T4) to survey medium- and large-sized mammals in a Pampa region, southern Brazil. The white areas on the map represent native grassland.

diurnal ( $\geq 70 \%$ of records occurring during the day), nocturnal ( $\geq 70 \%$ of records during the night), crepuscular (from 50 to $60 \%$ of records during crepuscular periods), crepuscular/nocturnal (from 60 to $70 \%$ of records during the night and crepuscular periods), crepuscular/diurnal (from 60 to $70 \%$ of records during the day and crepuscular periods) or cathemeral, when records were randomly distributed along the daily cycle. Following Gómez et al. (2005), crepuscular records were those occurring within $1 \mathrm{~h}$ before or after sunrise or sunset.

To estimate the abundance of $C$. paca all non-sequential photographs at intervals $\geq 15 \mathrm{~min}$ were analysed. Individuals were identified by the differences in the patterns of flank spots, which are individually unique. Such methods are commonly used for studying species with variable natural coat markings, including large cats (e.g. tiger, Panthera tigris (Linnaeus, 1758), Karanth, 1995; Karanth and Nichols, 1998; jaguar, Panthera onca (Linnaeus, 1758), Silver et al., 2004; Soisalo and Cavalcanti, 2006; Paviolo et al., 2008) and smaller species (e.g. ocelot Leopardus pardalis (Linnaeus, 1758), Bitetti et al., 2009; Kasper et al., 2015, and Geoffroy's cat, Leopardus geoffroyi (D’Orbigny \& Gervais, 1844; Cuellar et al., 2006).
Consequently, it was possible to count the number of individuals and also to record where and when they were located. We just used photographs of the right flank of the animals, since this was the most recorded side and each survey station had just a single camera. Images that did not permit accurate spot pattern identification were discarded. Estimates therefore represent the minimum number of individual C. paca present at the study site during the sampling period.

For density estimation, we considered two premises: 1) C. paca is restricted to riparian forest (although individuals may use peripheral environments when moving between riparian sites); and; 2) the probability that individuals resident at the study site will not be detected during the sample period is low.

Considering that sampling units (transects) were separated by $1,000 \mathrm{~m}$, we assumed a buffer zone of $500 \mathrm{~m}$ around each camera trap. In doing so, we assume that those individuals that use a linear home range smaller or equivalent to $500 \mathrm{~m}$ will be recorded at least once by one camera. The linear extension of riparian forest sampled was $4,220 \mathrm{~m}$, considering the linear distance between the transect 1 and the transect 4 . We added a buffer zone of $500 \mathrm{~m}$ (that represents a half distance between consecutive transects) before the transect 1 and after the 
transect 4 to obtain an effective sampled area, resulting in a total linear extension of 5,220 m. According with our first premise, we measured the area of riparian forest present in the sampling area, using Google Earth (Google Llc., 2013) and the extension Earth Point KML Shapes, which resulted in an area of $0.85 \mathrm{~km}^{2}$. We then estimated the minimum density of $C$. paca, using the number of individuals identified over the sampling period and the total extent of riparian forest cover within the study site. The camera trap images also allowed us to estimate movements for individuals recorded on more than one transect. Since the number of individuals recorded varied during each month, we also measured a monthly population density. However, although the camera stations were not equidistantly distributed spatial and temporal conclusion should be considered with caution.

Considering the population to be closed (Otis et al., 1978), we used capture/recapture analysis to estimate abundance during two periods of three consecutive months. However, due to the low rates of captures and recaptures, the deployed metric has low resolution power and our estimates should be considered carefully. We estimated population abundance using the Lincoln Petersen model, as modified by Schnabel for multiple occasions (Krebs, 1999).

\section{Results}

\subsection{Activity pattern}

We obtained 129 photographic records of 10 mammal species of seven orders, of which the Carnivora was the most represented (Table 1). The most frequently recorded species were: Cuniculus paca $(\mathrm{n}=52)$, Hydrochoerus hydrochaeris (Linnaeus, 1766) $(\mathrm{n}=23)$, Cerdocyon thous (Linnaeus, 1766) ( $\mathrm{n}=17)$, Mazama gouazoubira (G. Fischer [von Waldheim], 1814) $(\mathrm{n}=10)$ and Conepatus chinga (Molina, 1782) $(\mathrm{n}=10$, Table 1).

Cuniculus paca, C. chinga and H. hydrochaeris were classified as nocturnal. C. thous as crepuscular/nocturnal, and M. gouazoubira as cathemeral (Table 1).

The highest number of records for Cuniculus paca occurred between $01 \mathrm{~h} 00 \mathrm{~min}$ and $05 \mathrm{~h} 00 \mathrm{~min}(\mathrm{~N}=47$ : $90.4 \%$ ), with just five records from the crepuscular period (Figure 2A, Table 1). H. hydrochaeris had a bimodal activity pattern, with most images between $19 \mathrm{~h} 00 \mathrm{~min}$ and $22 \mathrm{~h} 00 \mathrm{~min}$ and $04 \mathrm{~h} 00 \mathrm{~min}$ to $06 \mathrm{~h} 00 \mathrm{~min}$, plus two records at 10h00min (Figure 2B). Cerdcyon thous was recorded between $00 \mathrm{~h} 00 \mathrm{~min}$ and $08 \mathrm{~h} 00 \mathrm{~min}$, with some scattered records at $18 \mathrm{~h} 00 \mathrm{~min}$ and at $20 \mathrm{~h} 00 \mathrm{~min}$ (Figure $2 \mathrm{C}$ ), while M. gouazoubira was active throughout the circadian cycle, though with a larger number of records at $10 \mathrm{~h} 00 \mathrm{~min}$ (Figure 2D). Conepatus chinga was recorded between $21 \mathrm{~h} 00 \mathrm{~min}$ and $08 \mathrm{~h} 00 \mathrm{~min}$ (Figure 2E).

\subsection{Density estimates}

For density estimates of C. paca we analysed 67 photographic records, of which 34 (51\%) permitted accurate identification of 10 individuals. Most individuals recorded $(\mathrm{N}=9$ ) occurred on just one transect (Table 2), though one was recorded on two transects within a linear distance of $1,140 \mathrm{~m}$. Of the ten individuals recorded, seven were registered during just 1 to 2 months and were

Table 1. Classification of the circadian activity pattern of medium and large wild mammals surveyed with camera traps at Passo Novo, Alegrete municipality, southern Brazil. Nomenclature and taxonomic arrangement follow Paglia et al. (2012). ( $\mathrm{N}=$ number of independent photographic records).

\begin{tabular}{|c|c|c|c|c|c|}
\hline \multirow{2}{*}{$\begin{array}{c}\text { Taxon } \\
\text { (Order and Species) }\end{array}$} & \multicolumn{3}{|c|}{ Percentage of Records (\%) } & \multirow{2}{*}{$\mathbf{N}$} & \multirow{2}{*}{ Activity Pattern } \\
\hline & Diurnal & Crepuscular & Nocturnal & & \\
\hline \multicolumn{6}{|l|}{ Didelphimorphia } \\
\hline Didelphis albiventris (Lund, 1840) & & 25.0 & 75.0 & 4 & \\
\hline \multicolumn{6}{|l|}{ Pilosa } \\
\hline Tamandua tetradactyla (Linnaeus, 1758) & & & 100 & 1 & \\
\hline \multicolumn{6}{|l|}{ Cingulata } \\
\hline Dasypus novemcinctus (Linnaeus, 1758) & & 11.1 & 88.9 & 9 & \\
\hline \multicolumn{6}{|l|}{ Artiodactyla } \\
\hline $\begin{array}{l}\text { Mazama gouazoubira } \\
\text { (G. Fischer [von Waldheim], 1814) }\end{array}$ & 50.0 & 10.0 & 40.0 & 10 & Cathemeral \\
\hline \multicolumn{6}{|l|}{ Carnivora } \\
\hline Cerdocyon thous (Linnaeus, 1766) & & 35.3 & 64.07 & 17 & Crepuscular/nocturnal \\
\hline Conepatus chinga (Molina, 1782) & 10.0 & 10.0 & 80.0 & 10 & Nocturnal \\
\hline Procyon cancrivorus (G.[Baron] Cuvier, 1798) & & & 100 & 2 & \\
\hline \multicolumn{6}{|l|}{ Lagomorpha } \\
\hline Lepus europaeus (Pallas, 1778) & & 100 & & 1 & \\
\hline \multicolumn{6}{|l|}{ Rodentia } \\
\hline Hydrochoerus hydrochaeris (Linnaeus, 1766) & 4.3 & 17.4 & 73.9 & 23 & Nocturnal \\
\hline Cuniculus paca (Linnaeus, 1766) & & 9.6 & 90.4 & 52 & Nocturnal \\
\hline Total & & & & 129 & \\
\hline
\end{tabular}




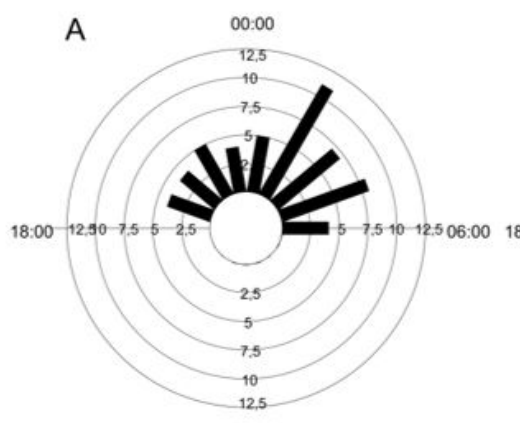

$12: 00$

C

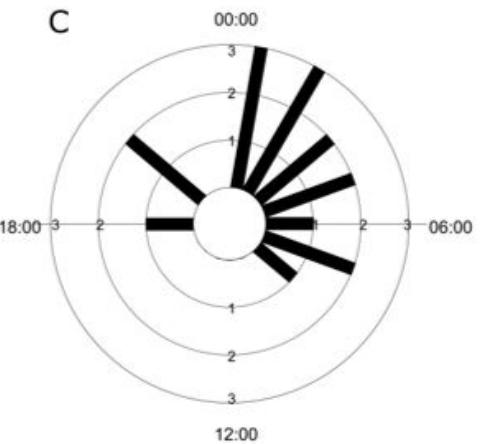

D

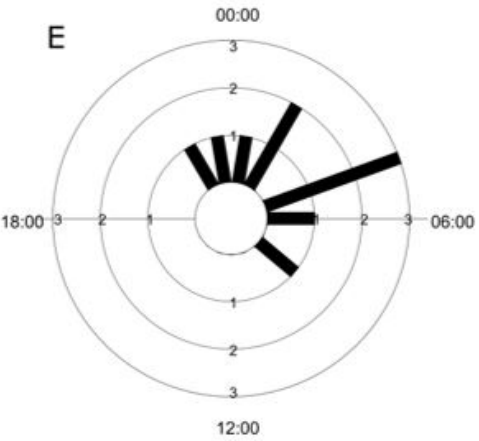

B $\quad 00: 00$

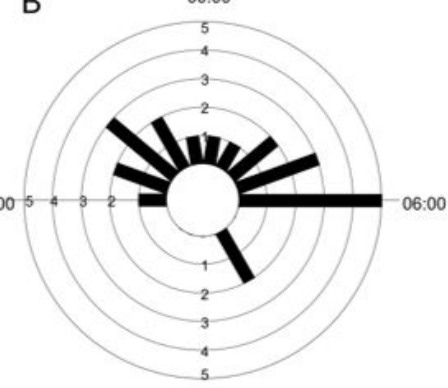

12:00

D $\quad 00: 00$

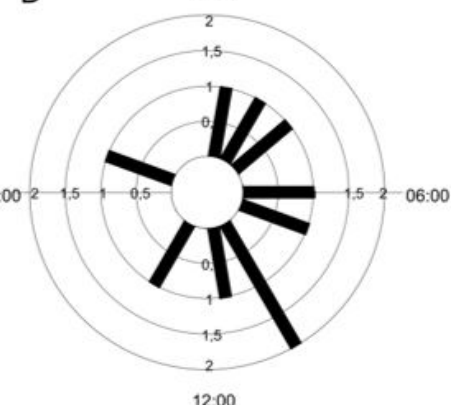

$12: 00$

Figure 2. Circular distribution of records of medium and large mammals in a region of the southern Brazilian Pampa: A) Cuniculus paca $(\mathrm{n}=52)$; B) Hydrochoerus hydrochaeris $(\mathrm{n}=23)$; C) Cerdocyon thous $(\mathrm{n}=17)$; D) Mazama gouazoubira $(\mathrm{n}=10)$; E) Conepatus chinga $(\mathrm{n}=10)$. The black bars represent the number of independent photographic records $(\mathrm{n})$ per hour.

Table 2. Records of ten individuals (ID) of Cuniculus paca by camera trap surveys from July 2014 to April 2015 in a riparian forest at the Passo Novo, Alegrete municipality, southern Brazil. Roman numerals represent those transects in which individuals were recorded and the number of records are given in parenthesis.

\begin{tabular}{|c|c|c|c|c|c|c|c|c|c|c|c|c|}
\hline \multirow{2}{*}{ ID } & \multicolumn{6}{|c|}{2014} & \multicolumn{6}{|c|}{2015} \\
\hline & Jul & Aug & Sep & Oct & Nov & Dec & Jan & Feb & Mar & Apr & May & Jun \\
\hline 1 & II (02) & & & & & & II (02) & & & & & \\
\hline 2 & II (01) & II (01) & & & & & & & & & & \\
\hline 3 & & II (09) & & & & & & & & & & \\
\hline 4 & II (01) & & & & & & & & & & & \\
\hline 5 & & & II (01) & & & & & & & & & \\
\hline 6 & & & & & & IV (03) & III (02) & IV (02) & & IV (01) & & \\
\hline 7 & & & & & & IV (01) & & IV (01) & & & & \\
\hline 8 & & & & & & & II (05) & & & & & \\
\hline 9 & & & & & & & II (01) & & & & & \\
\hline 10 & & & & & & & & & I (01) & & & \\
\hline
\end{tabular}


considered transients. Three individuals were recorded during 4, 6 and 8 months and where considered to be residents (Table 2). Therefore, if only resident individuals are considered, the minimum density of this population during the monitoring period was 3.5 individuals per $\mathrm{km}^{2}$. For the two sampling periods (2014 and 2015), and including transient individuals, the estimated density varied from 7.1 to $8.2 \mathrm{ind} / \mathrm{km}^{2}$. Using only the number of individuals recorded monthly at the study site, the minimal average density was $2.4 \mathrm{ind} / \mathrm{km}^{2}(\mathrm{SD}=1.67)$.

We calculated population abundance for two three-month periods (July-September 2014 and January-March 2015). During each period we recorded five individuals. Capture/recapture analysis produced a population estimate of 8 and 10 individuals for each period, respectively. These estimates allowed us to calculate respective densities of 9.4 and 11.8 individuals per $\mathrm{km}^{2}$.

\section{Discussion}

In the present study, most species were recorded more frequently at night. Cuniculus paca was the most frequent recorded species. The nocturnal pattern observed for C. paca in the study area is in line with that reported by other studies (Donadio et al., 2001; Gómez et al., 2005; Michalski and Norris, 2011; Blake et al., 2012; Kasper et al., 2012b; Huck et al., 2013), although Pérez (1992) had suggested a crepuscular habit for the species. At Passo Novo, most activity was recorded between $01 \mathrm{~h} 00 \mathrm{~min}$ and $05 \mathrm{~h} 00 \mathrm{~min}$, with just five crepuscular records. This variation in activity may be related to regional differences.

Hydrochoerus hydrochaeris had a nocturnal activity pattern, with $17 \%$ of the records occurring during the crepuscular period. Data from other studies have found activity patterns that ranged from nocturnal (Rinaldi, 2014) to cathemeral (Rinaldi, 2014; Foster et al., 2013; Gómez et al., 2005). Rodrigues (2013) observed a relationship between capybaras activity pattern and thermal conditions. In the Pantanal, the species presented peaks of activity during the day and in the early evening, probably to avoid predation risk by the nocturnal Panthera onca and Puma concolor (Linnaeus, 1771) (Foster et al., 2013).

Cerdocyon thous showed a crepuscular/nocturnal activity pattern, with a higher concentration of records at night. The species is described as nocturnal by many authors (Courtenay and Maffei, 2004; Vieira and Port, 2007; Bitetti et al., 2009; Tortato and Althoff, 2009; Faria-Corrêa et al., 2009), but it is also known to forage during the day (Brady, 1979; Nascimento et al., 2004), since its activity seems to be correlated with the activity of prey. In areas with sympatry with Lycalopex gymnocercus (G. Fischer, 1814), both species may segregate their activity patterns to avoid encounters (Vieira and Port, 2007; Bitetti et al., 2009). Although L. gymnocercus was not recorded in the present study, its occurrence was expected as it is known for the region (Kasper et al., 2012a).

Mazama gouazoubira had a cathemeral activity pattern. This has also been observed by Gómez et al. (2005) in the Amazon. The cathemeral pattern is expected for such herbivorous mammals, as the strategy guarantees energetic requirements based on a low quality diet (Donati et al., 2007). However, M. gouazoubira has been recorded being primarily diurnal in the Pantanal (Chiaravalloti et al., 2010), Amazonian Peru (Tobler et al., 2009) and Ecuador (Blake et al., 2012). At these sites this may represent a strategy to avoid resources competition with other cervids, such as Mazama americana (Erxleben, 1777) (Tobler et al., 2009).

The nocturnal pattern of $C$. chinga reported in this study was also observed by a telemetry study of the species in the Brazilian Pampa region (Kasper et al., 2012b). The same authors reported an activity focus between $20 \mathrm{~h} 00 \mathrm{~min}$ and 03h00min, with activities beginning after sunset and ending near sunrise. The few records observed at the beginning of the day in our study may represent individuals returning to their dens, where they may remain throughout the day (Kasper et al., 2012b).

Considering that the circadian cycle of animals is regulated by periodic signals, such as the daily light-dark cycle and that the Pampa represents the southern limit of the distribution of many species, such as jaguar, tapir, margay, crab eating fox and agouti (Redford and Eisemberg, 1992), the longer nocturnal period in this region (at least during the austral winter) may affect species activity patterns. However, other factors, such as food availability and social interactions, can also affect the biological clock of some species (Mistlberger and Skene, 2004; Mistlberger and Antle, 2011). The study area is known to be under high hunting pressure (Peters et al., 2011), which may also affect the activity patterns of the sampled species (Kitchen et al., 2000; Vieira and Port, 2007; Martin and Reále, 2008; Norris et al., 2010). Consequently, the activity pattern observed for some medium and large mammals in the Pampa region may be related not just to evolutionary, biological and ecological aspects (Bitetti et al., 2009; Tobler et al., 2009; Chiaravalloti et al., 2010; Foster et al., 2013), but also to human impacts not measured here.

Cuniculus paca is considered an important game animal throughout its range (Emmons, 2016), and hunting can affect the density of local populations (Valsecchi et al., 2014). Methods for density estimation for this species have not been standardized, generating densities estimates varying from 3.5 individuals $/ \mathrm{km}^{2}$ in Peru (Emmons, 1987) to 93 individuals $/ \mathrm{km}^{2}$ (Beck-King et al., 1999) in Costa Rica. Several studies report C. paca in high abundance, such as Santos-Moreno and Perez-Irineo (2013) and Eisenberg and Thorington (1973) but it seems unrealistic compared to our study area. A possible explanation, suggested by Beck-King et al. (1999), linked high C. paca abundance to high fruit availability. Our study site is located in a temperate zone, at the limit of species distribution, were fruits are scare comparing to tropical forests. In the present study we estimated a minimal density of C. paca of $3.5 \mathrm{ind} / \mathrm{km}^{2}$. Since we used only resident individuals, this is a conservative estimate, although we assumed we have recorded all transient individuals during the survey. When recalculated using all individual recorded, density 
estimations varied from 7.1 to 8.2 individuals per $\mathrm{km}^{2}$. Based on capture/recapture analysis, local C. paca population size could range from 9.4 to 11.8 individuals depending on the time period. However, these estimations should be considered with caution, because capture and recapture rates are statistically limited. Aquino et al. (2009) showed that human hunting pressure is an important variable in determining agouti abundance. Considering that hunting commonly occurs in the Pampas' region (Peters et al., 2011), and agouti is considered an important game species (Aquino et al., 2009; Valsecchi et al., 2014; Emmons, 2016), the low density of this species recorded at the study site may indicate a response to long-term intensive hunting pressure, but more studies are needed to evaluate the impact of hunting on the maintenance of this species and other wildlife populations in the Pampa.

Most individuals were recorded in a single transect, which could be a response of habitat preference, since this site was located in the most extensive block of riparian vegetation at the study area. However, we should also consider that the transects were not sampling simultaneously and the virtual preference of a transect may also be an effect of the temporarily availability of food, since the species is primarily frugivorous (Perez, 1992). The species is also known to have a strong preference for forested areas (Pérez, 1992; Bonvicino et al., 2008), and in the Pampa region, especially at the study site, forests are restricted to riparian areas. Consequently, such areas may be the major habitats for Pampas-dwelling C. paca (Leuchtenberger et al., 2016). Under such circumstances, C. paca density could be calculated in linear proportion to length of adjacent water course. In the current instance, this would represent one individual for every $1,600 \mathrm{~m}$ of water body.

The Pampa region is the least protected Brazilian Biome and one of the poorest known biologically (Roesch et al., 2009). Although the study area represents a small portion of the Pampa Biome, this site has a representative assemblage of the medium and large mammals expected for the region. Considering the intensity and range of economic activities threatening the biological integrity of this Biome, an increase in efforts to develop scientific studies is urgently required as is the adoption of effective conservation plans to protect this ecosystem.

\section{Acknowledgements}

We are thankful to the Federal Institute Farroupilha-Alegrete Campus, for their logistic support. To FAPERGS for a scholarship to L.C. (number 264/2014). Patrick Ezequiel Fagundes Camargo and Daniel Batista de Araújo provided field sampling assistance. Adrian Barnett helped with the English. Flávia Tirelli revised the draft manuscript.

\section{References}

AQUINO, R., GIL, D. and PEZO, E., 2009. Ecological aspects and hunting sustainability of paca (Cuniculus paca) in the Itaya river basin, Peruvian Amazonia. Revista Peruana de Biología, vol. 16 , no. 1 , pp. 67-72.
BECK-KING, H., HELVERSEN, O. and BECK-KING, R., 1999. Home range, population density, and food resources of Agouti paca (Rodentia: Agoutidae) in Costa Rica: a study using alternative methods. Biotropica, vol. 31, no. 4, pp. 675-685. http://dx.doi. org/10.1111/j.1744-7429.1999.tb00417.x.

BITETTI, M.S., BLANCO, Y.E., PEREIRA, J.A., PAVIOLO, A. and PÍREZ, I.J., 2009. Time partitioning favors the coexistence of sympatric crab-eating foxes (Cerdocyon thous) and pampas foxes (Lycalopex gymnocercus). Journal of Mammalogy, vol. 90, no. 2, pp. 479-490. http://dx.doi.org/10.1644/08-MAMM-A-113.1.

BLAKE, J.G., MOSQUERA, D., LOISELLE, B.A., SWING, K., GUERRA, J. and ROMO, D., 2012. Temporal activity patterns of terrestrial mammals in lowland rainforest of eastern Ecuador. Ecotropica (Bonn), vol. 137, no. 18, pp. 137-146.

BONVICINO, C.R., OLIVEIRA, J.A. and D'ANDREA, P.S., 2008. Guia de roedores do brasil: com chaves para gêneros baseados em caracteres externos. Rio de Janeiro: Centro PanAmericano de Febre Aftosa, Organização Pan-Americana da Saúde, Organização Mundial da Saúde, 120 p.

BRADY, C.A., 1979. Observation on the behavior and ecology of the crab-eating fox (Cerdocyon thous). In: J.F. EISENBERG, ed. Vertebrate ecology in the northern neotropics. Washington: Smithsonian Institute Press, pp. 161-171.

CHIARAVALLOTI, R.M., TOMAS, W.M., CAMILO, A.R., TOMÁS, M.A., SANTOS, L.G.O., MOZERLE, H.B., BOLZAN, A. and BODMER, R., 2010. Separação de nicho entre duas espécies simpátricas de veados do gênero Mazama em uma paisagem complexa no Pantanal. In: Anais do Simpósio sobre recursos naturais e sócio-econômicos do Pantanal, 10 nov. 2010, Corumbá. Corumbá: Embrapa Pantanal, CD Rom.

COSTA, P.C., LEITE, Y.L.R., MENDES, S.L. and DITCHFIELD, A.D., 2005. Mammal conservation in Brazil. Conservation Biology, vol. 19, no. 3, pp. 672-679. http://dx.doi.org/10.1111/j.15231739.2005.00666.x.

COURTENAY, O. and MAFFEI, L., 2004. Cerdocyon thous (Linnaeus, 1766). In: C. SILLERO-ZUBIRI, M. HOFFMAN and D.W. MACDONALD, eds. Canids: foxes, wolves, jackals and dogs, status survey and conservation action plan. Gland: IUCN-SSC Canid Specialist Group, pp. 32-38.

CUELLAR, E., MAFFEI, L., ARISPE, R. and NOSS, A.J., 2006. Geoffroy's cats at the northern limit of their range: activity patterns and density estimates from camera trapping in Bolivian dry forests. Studies on Neotropical Fauna and Environment, vol. 41, no. 3, pp. 169-178. http://dx.doi.org/10.1080/01650520600840001.

DIBNER, C., SCHIBLER, U. and ALBRECHT, U., 2010. The mammalian circadian timing system: organization and coordination of central and peripheral clocks. Annual Review of Physiology, vol. 72, no. 1, pp. 517-549. PMid:20148687. http://dx.doi.org/10.1146/ annurev-physiol-021909-135821.

DONADIO, E., MARTINO, S., AUBONE, M. and NOVARO, A.J., 2001. Activity patterns, home-range, and habitat selection of the common hog-nosed skunk, Conepatus chinga (Mammmalia, Mustelidae), in northwestern Patagonia. Mammalia, vol. 65, no. 1, pp. 49-54. http://dx.doi.org/10.1515/mamm.2001.65.1.49.

DONATI, G., BOLLEN, A., BORGOGNINI-TARLI, S.M. and GANZHORN, J.U., 2007. Feeding over the 24-h cycle: dietary flexibility of cathemeral collared lemurs (Eulemur collaris). Behavioral Ecology and Sociobiology, vol. 61, no. 8, pp. 12371251. http://dx.doi.org/10.1007/s00265-007-0354-x. 
EISENBERG, J.F. and REDFORD, K.H., 1999. Mammals of the Neotropics - The Central Neotropics: Ecuador, Peru, Bolivia, Brazil. Chicago: University Chicago Press, 609 p.

EISENBERG, J.F. and THORINGTON, R.W. Jr., 1973. A Preliminary Analysis of a Neotropical Mammal Fauna. Biotropica, vol. 5, no. 3, pp. 150-161. http://dx.doi.org/10.2307/2989807.

EMMONS, L., 2016. Cuniculus paca. Cambridge: The IUCN Red List of Threatened Species.

EMMONS, L.H., 1987. Comparative feeding ecology of felids in a neotropical rainforest. Behavioral Ecology and Sociobiology, vol. 20, no. 4, pp. 271-283. http://dx.doi.org/10.1007/BF00292180.

ESPINOSA, C.C., GALIANO, D., KUBIAK, B.B. and MARINHO, J.R., 2016. Medium- and large-sized mammals in a steppic savanna area of the Brazilian Pampa: survey and conservation issues of a poorly known fauna. Brazilian Journal of Biology $=$ Revista Brasileira de Biologia, vol. 76, no. 1, pp. 73-79. http://dx.doi. org/10.1590/1519-6984.12714.

FARIA-CORREAA, M., BALBUENO, R.A., VIEIRA, E.M. and FREITAS, T.R.O., 2009. Activity, habitat use, density, and reproductive biology of the crab-eating fox (Cerdocyon thous) and comparison with the pampas fox (Lycalopex gymnocercus) in a Restinga area in the southern Brazilian Atlantic Forest. Mammalian Biology, vol. 74, no. 3, pp. 220-229. http://dx.doi. org/10.1016/j.mambio.2008.12.005.

FOSTER, R.J. and HARMSEN, B.J., 2011. A critique of density estimation from camera-trap data. The Journal of Wildife Management, vol. 76, no. 2, pp. 224-236. http://dx.doi.org/10.1002/jwmg.275.

FOSTER, V.C., SARMENTO, P., SOLLMANN, R., TÔRRES, N., JÁCOMO, A.T.A., NEGRÕES, N., FONSECA, C. and SILVEIRA, L., 2013. Jaguar and puma activity patterns and predator-prey interactions in four Brazilian biomes. Biotropica, vol. 45, no. 3, pp. 373-379. http://dx.doi.org/10.1111/btp.12021.

GOOGLE LLC., 2013 [viewed 22 April 2015]. Google Earth. v. 7.1.5.1557 [software]. Mountain View: Google. Alegrete, Rio Grande do Sul, 11 June 2013, 2942’37.04”S, 55³2’18.58”W, Eye alt $4.32 \mathrm{~km}$, DigitalGlobe2015. Available from: http://www. earth.google.com

GÓMEZ, H., WALLACE, R.B., AYALA, G. and TEJADA, R., 2005. Dry season activity periods of some Amazonian mammals. Studies on Neotropical Fauna and Environment, vol. 40, no. 2, pp. 91-95. http://dx.doi.org/10.1080/01650520500129638.

GUDYNAS, E., 1989. The conservation status of South American rodents: many questions but few answers. In: W.Z. LIDICKER, ed. Rodents: a world survey of species of conservation concern - proceedings of a Workshop of the IUCN/SSC Rodent Specialist Group, Held at the Fourth International Theriological Congress, 17 August 1985, Edmonton, Alberta, Canada. Gland: IUCN, pp. 20-25.

HASENACK, H. and CORDEIRO, J.L.P. (orgs.), 2006 [viewed 3 august 2015]. PROBIO - cobertura vegetal do bioma Pampa: relatório técnico [online]. Porto Alegre: Centro de Ecologia, Universidade Federal do Rio Grande do Sul; Brasília: Secretaria de Biodiversidade e Florestas, Ministério do Meio Ambiente, 30 p. Available from: http://www.ecologia.ufrgs.br/labgeo/arquivos/ Publicacoes/Relatorios/2007/Relatorio_bioma_Pampa.pdf

HUCK, M., JUÁREZ, C.P., ROTUNDO, M.A. and FERNÁNDEZDUQUE, E., 2013. Primera evidencia craneal y registros documentados de Cuniculus paca (Rodentia, Cuniculidae) para el chaco húmedo de Argentina. Mastozoología Neotropical, vol. 20, no. 1 , pp. 153-157.

INSTITUTO BRASILEIRO DE GEOGRAFIA E ESTATÍSTICA - IBGE, 2004 [viewed 3 august 2015]. Mapas dos Biomas e de Vegetação [online]. Rio de Janeiro: IBGE. Available from: http://www. ibge.gov.br/home/ presidencia/noticias/21052004biomashtml.shtm

INSTITUTO BRASILEIRO DE GEOGRAFIA E ESTATÍSTICA - IBGE, 2012 [viewed 3 august 2015]. Manual técnico da vegetação brasileira [online]. Rio de Janeiro: IBGE. Available from: ftp://geoftp.ibge.gov.br/documentos/recursos_naturais/ manuais_tecnicos/manual_tecnico_vegetacao_brasileira.pdf

KARANTH, K.U. and NICHOLS, J.D., 1998. Estimation of tiger densities in India using photographic captures and recaptures. Ecology, vol. 79, no. 8, pp. 2852-2862. http://dx.doi. org/10.1890/0012-9658(1998)079[2852:EOTDII]2.0.CO;2.

KARANTH, K.U., 1995. Estimating tiger Panthera tigris populations from camera-trap data using capture recapture models. Biological Conservation, vol. 71, no. 3, pp. 333-338. http://dx.doi. org/10.1016/0006-3207(94)00057-W.

KASPER, C.B., BASTAZINI, V.A.G., SOARES, J.B.G. and FREITAS, T.R.O., 2012a. Abundance of Conepatus chinga (Carnivora, Mephitidae) and other medium-sized mammals in grasslands of southern Brazil. Iheringia. Série Zoologia, vol. 102, no. 3, pp. 303-310. http://dx.doi.org/10.1590/S007347212012000300009 .

KASPER, C.B., SOARES, J.B.G. and FREITAS, T.R.O., 2012b. Differential patterns of home-range, net displacement and resting sites use of Conepatus chinga in southern Brazil. Mammalian Biology, vol. 77, no. 5, pp. 358-362. http://dx.doi.org/10.1016/j. mambio.2012.03.006

KASPER, C.B., MAZIM, F.D., SOARES, J.B.G. and OLIVEIRA, T.G., 2015. Density estimates and conservation of Leopardus pardalis southernmost population of the Atlantic Forest. Iheringia. Série Zoologia, vol. 105, no. 3, pp. 367-371. http://dx.doi. org/10.1590/1678-476620151053367371.

KITCHEN, A.M., GESE, E.M. and SCHAUSTER, E.R., 2000. Changes in coyote activity patterns due to reduced exposure to human persecution. Canadian Journal of Zoology, vol. 78, no. 5, pp. 853-857. http://dx.doi.org/10.1139/z00-003.

KÖPPEN, W., 1948. Climatologia: con un estúdio de los climas de la tierra. México: Fundo de Cultura Econômica, 478 p.

KOVACH, W.L., 2011. Oriana: circular statistics for windows. Pentraeth: Kovach Computing Services, 171 p.

KREBS, C.J., 1999. Ecological methodology. 2nd ed. New York: Addison-Wesley Longman, $652 \mathrm{p}$.

LEUCHTENBERGER, C., TIRELLI, F.P., MAZIM, F.D., PETERS, F.B., OLIVEIRA, E.S., CARIOLATTO, L. and QUEIROLO, D., 2016. New records of Cuniculus paca (Rodentia: Cuniculidae) in a temperate grassland dominated landscape of Pampas region of Brazil and Uruguay. Mammalia, vol. 81, no. 4, pp. 1-4. http:// dx.doi.org/10.1515/mammalia-2015-0129.

MARTIN, J.G.A. and REÁLE, D., 2008. Animal temperament and human disturbance: implications for the response of wildlife to tourism. Behavioural Processes, vol. 77, no. 1, pp. 66-72. PMid:17683881. http://dx.doi.org/10.1016/j.beproc.2007.06.004.

MICHALSKI, F. and NORRIS, D., 2011. Activity pattern of Cuniculus paca (Rodentia: Cuniculidae) in relation to lunar illumination and other abiotic variables in the southern Brazilian 
Amazon. Zoologia, vol. 28, no. 6, pp. 701-708. http://dx.doi. org/10.1590/S1984-46702011000600002.

MISTLBERGER, R.E. and ANTLE, M.C., 2011. Entrainment of circadian clocks in mammals by arousal and food. Essays in Biochemistry, vol. 49, no. 1, pp. 119-136. PMid:21819388. http:// dx.doi.org/10.1042/bse0490119.

MISTLBERGER, R.E. and SKENE, D.J., 2004. Social influences on mammalian circadian rhythms: animal and human studies. Biological Reviews of the Cambridge Philosophical Society, vol. 79, no. 3, pp. 533-556. PMid:15366762. http://dx.doi.org/10.1017/ S1464793103006353.

NASCIMENTO, V.L., FERREIRA, J.A., FREITAS, D.M., SOUSA, L.L., BORGES, P.A.L. and TOMAS, W.M., 2004. Período de atividade de alguns vertebrados do Pantanal, estimado por fotografia remota. In: Anais do Simpósio sobre recursos naturais e sócio-econômicos do pantanal, 23-26 Novembro 2004, Corumbá. Corumbá: Embrapa Pantanal, CD-Rom.

NORRIS, D., MICHALSKI, F. and PERES, C.A., 2010. Habitat patch size modulates terrestrial mammal activity patterns in Amazonian forest fragments. Journal of Mammalogy, vol. 91, no. 3, pp. 551-560. http://dx.doi.org/10.1644/09-MAMM-A-199.1.

OTIS, D.L., BURNHAM, K.P., WHITE, G.C. and ANDERSON, D.R., 1978. Statistical inference from capture data on closed animal populations. Bethesda: The Wildlife Societ, 135 p. Wildlife Monographs, no. 62.

PAGLIA, A.P., FONSECA, G.A.B., RYLANDS, A.B., HERRMANN, G., AGUIAR, L.M.S., CHIARELLO, A.G., LEITE, Y.L.R., COSTA, L.P., SICILIANO, S., KIERULFF, M.C.M., MENDES, S.L., TAVARES, V.C., MITTERMEIER, R.A. and PATTON, J.L., 2012. Lista anotada dos mamiferos do Brasil/annotated checklist of brazilian mammals. Arlington: Conservation International, 76 p. Occasional Papers in Conservation Biology, no. 6.

PATTON, J.L., 2015. Family Cuniculidae G. S. Miller and Gidley, 1918. In: J.L. PATTON, U.F.J. PARDIÑAS and G. D'ELÍA, eds. Mammals of South America: rodents. vol. 2. Chicago: The University of Chicago Press, pp. 726-733.

PAVIOLO, A., ANGELO, C.D., BLANCO, Y.E. and BITETTI, M.S., 2008. Jaguar Panthera onca population decline in the Upper Paraná Atlantic Forest of Argentina and Brazil. Oryx, vol. 42, no. 04, pp. 554-561. http://dx.doi.org/10.1017/S0030605308000641.

PÉREZ, E.M., 1992. Agouti paca. Mammalian Species, no. 404, pp. 1-7. https://doi.org/10.2307/3504102.

PETERS, F.B., ROTH, P.R.O., PEREIRA, M.S., PISKE, A.D. and CHRISTOFF, A.U., 2011. Aspectos da caça e perseguição aplicada à mastofauna na área de proteção ambiental do Ibirapuitã, Rio Grande do Sul, Brasil. Biodiversidade Pampeana, vol. 9, no. 1, pp. 16-19.

PINTO, L.C. and DUARTE, M.M., 2013. Occurrence (new record) of maned wolf Chrysocyon brachyurus (Illiger, 1815) (Carnivora, Canidae) in southern Brazil. Ciência Florestal, vol. 23, no. 1, pp. 253-259. http://dx.doi.org/10.5902/198050988459.

REDFORD, K.H. and EISEMBERG, J.F., 1992. Mammals of the Neotropics - the southern cone: Chile, Argentina, Uruguay, Paraguay. vol. 2. Chicago: The University of Chicago Press, $460 \mathrm{p}$.
RINALDI, A.R., 2014. Ecologia de capivaras (Hydrochoerus hydrochaeris, Linnaeus, 1766) em região alterada pela formação de um reservatório hidrelétrico. Curitiba: Universidade Federal do Paraná, 200 p. Dissertação de Doutorado em Ecologia e Conservação.

RODRIGUES, M.V., 2013. Comportamento de um grupo de capivaras em uma área urbanizada. Acta Veterinaria Brasilica, vol. 7, no. 3, pp. 212-217.

ROESCH, L.F.W., VIEIRA, F.C.B., PEREIRA, V.A., SCHÜNEMANN, A.L., TEIXEIRA, I.F., SENNA, A.J.T. and STEFENON, V.M., 2009. The Brazilian Pampa: a fragile Biome. Diversity (Basel), vol. 1, no. 2, pp. 182-198. http://dx.doi.org/10.3390/d1020182.

SANTOS-MORENO, A. and PEREZ-IRINEO, G., 2013. Abundancia de tepezcuintle (Cuniculus paca) y relación de su presencia con la de competidores y depredadores en una selva tropical. Therya, vol. 4, no. 1, pp. 89-98. http://dx.doi.org/10.12933/therya-13-97.

SIDELL, B.P., 2002. Moonrise 3.5 - 32 Bit [software]. Informer Technologies, Inc.

SILVA, F., 2014. Mamiferos silvestres do Rio Grande do Sul. 3rd ed. Porto Alegre: Fundação Zoobotânica do Rio Grande do Sul, $308 \mathrm{p}$

SILVER, S.C., OSTRO, L.E.T., MARSH, L.K., MAFFEI, L., NOSS, A.J., KELLY, M.J., WALLACE, R.B., GÓMEZ, H. and AYALA, G., 2004. The use of camera traps for estimating jaguar Panthera onca abundance and density using capture/recapture analysis. Oryx, vol. 38, no. 02, pp. 148-154. http://dx.doi. org/10.1017/S0030605304000286.

SOISALO, M.K. and CAVALCANTI, S.M.C., 2006. Estimating the density of a jaguar population in the Brazilian Pantanal using camera-traps and capture-recapture sampling in combination with GPS radio-telemetry. Biological Conservation, vol. 129, no. 4, pp. 487-496. http://dx.doi.org/10.1016/j.biocon.2005.11.023.

TOBLER, M.W., CARRILLO-PERCASTEGUI, E.S. and POWELL, G., 2009. Habitat use, activity patterns and use of mineral licks by five species of ungulate in south-eastern Peru. Journal of Tropical Ecology, vol. 25, no. 03, pp. 261-270. http:// dx.doi.org/10.1017/S0266467409005896.

TORTATO, F.R. and ALTHOFF, S.L., 2009. Avaliação de fatores abióticos sobre o período de atividade do graxaim (Cerdocyon thous, Carnivora: Canidae). Biotemas, vol. 22, no. 4, pp. 147-152. http://dx.doi.org/10.5007/2175-7925.2009v22n4p147.

VALSECCHI, J., EL BIZRI, H.R. and FIGUEIRA, J.E.C., 2014. Subsistence hunting of Cuniculus pacain the middle of the Solimões River, Amazonas, Brazil. Brazilian Journal of Biology $=$ Revista Brasileira de Biologia, vol. 74, no. 3, pp. 560-568. http://dx.doi. org/10.1590/bjb.2014.0098.

VIEIRA, E.M. and PORT, D., 2007. Niche overlap and resource partitioning between two sympatric fox species in southern Brazil. Journal of Zoology, vol. 272, no. 1, pp. 57-63. http://dx.doi. org/10.1111/j.1469-7998.2006.00237.x.

WRIGHT, S.J., ZEBALLOS, H., DOMÍNGUEZ, I., GALLARDO, M.M., MORENO, M.C. and IBÁÑEZ, R., 2000. Poachers alter mammal abundance, seed dispersal, and seed predation in a Neotropical forest. Conservation Biology, vol. 14, no. 1, pp. 227-239. http://dx.doi.org/10.1046/j.1523-1739.2000.98333.x. 